\title{
Good governance in natural resource management: a case study from Dolpa district, Nepal
}

\begin{abstract}
Ripu M. Kunwar ${ }^{1 *}$ and Rudriksha Rai Parajuli ${ }^{2}$
Present paper analyses good governance practices of community based organizations of Dolpa district in management of natural resources. Adequate participation, fund mobilization for livelihood diversification and transparent \& accountable financial transactions were efficient proponents. However, participatory monitoring, post formation supports and incentives for income generation and entrepreneurship were imperative for sustainable natural resource management and livelihoods which are possible through clarifying resources, roles, responsibilities, rules and rights among stakeholders.
\end{abstract}

Key words: Good governance, natural resource management, participation, livelihood, Dolpa

$\mathbf{S}_{\mathrm{b}}^{\mathrm{h}}$ hey-Phoksundo National Park (SPNP) and its buffer zone area covering nine villages of Dolpa and two villages of Mugu district, is located in the Midwestern Himalayan region of Nepal. SheyPhoksundo, the largest national park of Nepal, including Shey monastery at $4480 \mathrm{~m}$ height and magnificent Phoksundo lake at $3150 \mathrm{~m}$, the Nepal's deepest and second largest lake, accounts unique trans-Himalayan ecosystem. The ecosystem along with sprawling landscape and large meadows provides critical habitat for unique biodiversity and natural beauty and harbors many endemic, threatened and ethnobotanically useful medicinal plants (Kunwar and Duwadee 2003). Owing to these unique ecological characteristics along with socio-cultural systems (oldest Tibetan culture Bon Po, traditional health care system $A m c h i$ and a human settlement at the highest altitude at Dho Tarap valley, Dolpa), the area (park) has been proposed to enlist in World Heritage Site (WHS) and Ramsar site.

Agriculture, animal husbandry and trade of medicinal plants are major livelihood portfolios in SPNP and buffer zone areas. Forest and pasture resources are important ones in the Himalayas (Ives 2006) for energy, fodder, and timber needs of local people. Poaching, illegal and unsustainable harvesting of NTFPs, inadequate data for management of biodiversity resources, limited park resources and unfavorable political situations posed constraints for conservation and management of these natural resources. WWF Nepal and CARE Nepal have jointly

\footnotetext{
${ }^{1}$ Centre for Biological Conservation, Nepal.

2 WWF Nepal, Kathmandu Nepal

* Author for correspondence: E-mail: rkunwar@gmail.com
}

launched Strengthened Actions for Governance in Utilization of Natural Resources (SAGUN) program to sustainably manage the natural resources. Principally, it ensures that the natural resources are managed in a democratic way, the performance of selected institutions is improved to meet the principles of good governance and participation and in particular, the benefits derived from natural resources are dispersed/distributed in accountable and transparent way to the local communities. Further, the program envisions that there is increased productivity of natural resources under local management. In this context, the present study aimed at assessing the natural resource management (NRM) practices of local communities and institutions particularly focusing on good governance fundamentals.

\section{Methodology}

The area chosen for study was Shey-Phoksundo National Park and its buffer zone area. Reconnaissance field visit was carried out in between November 2006 to December 2006. Local communities/individuals and institutions from the sampling sites:- Dunai, Raha, Phoksundo and Tripurakot VDCs (representing field sites and program office of SAGUN/Northern Mountain Conservation Project-NMCP, Dolpa) were consulted. Altogether, 105 respondents representing various organizations, government counter parts, line agencies, federations and associations, were 
interacted. Few of them were taken as key respondents to verify and cross check the information. Stakeholder analysis was done for secondary data collection and recording. Individual as well as group/community level consultations together with formal and informal interviews, discussion, interactions, attitude and behavioral assessments, and observations were carried out to acquire the necessary information. Besides, progress reports, research papers, management plans, baseline study, brochures, bulletins, working documents, etc. were reviewed. The schedule matrix used to account the efficacy of the individuals and institutions in this study was adopted from SAMARPAN/CARE Nepal and it was slightly modified for gathering information in convenient way.

\section{Results \& discussion}

\section{Governance and good governance-History}

Governance is the practice of power for the management of economic and social resources in the development of the state (Kafle 2060). It integrates the mechanisms, processes and institutions through which all the stakeholders (the state, private sector and civil society) and citizens articulate their interests. It is all about the rules (UNDP 1999) that answer the questions who, what and how decisions are made and enforced.

Nepal's history and civilization was started before 5561 BC. In earlier days, the governance was procured by the guidance of scripture and tutors with considering the rules of Vaba, Mahabharata, Upanishada, Geeta, Ramayan, etc. During the reign of Ranas in 1846-1950, some liberal rules and regulations were sanctioned. After the initiation of democracy in 1950, there were more liberal policies, rule and regulations and gradual progress/increase in efficacy of governance system since then. During 1960-1990 the Panchayat system was established and the country was administered under five regions, 14 zones and 75 districts as a form of decentralization. Multiparty democracy system was reinstated with the King as a constitutional monarch after 1990.

Good governance is at forefront in natural resource management and development discourse (Mc Dougall et al. 2004). It accounts for the sustainable management of resources and livelihoods. The striking features in good governance are effectiveness, responsiveness, accountability, participatory, predictability, transparency and equitability; and social justice, economic liberalization, political pluralism, and administrative accountability (Fowler 1998). The good governance was first used in Nepal in Human Development Index (HDI) report of Nepal -1997 (UNDP, 1997). Later on, the word has frequently been used. Devolution of forest resource management policies is presented in table 1 and 2 .

Table 1: Historical timeline of the forest resource management policies in Nepal

\begin{tabular}{ll}
\hline Up to 1846 & Conversion of forests into agricultural lands \\
$1846-1950$ & Exploitation and privatization of forests \\
1957 & Private Forest Nationalization Act \\
1961 & Forest Act \\
1967 & Forest Preservation Act \\
1976 & National Forestry Plan \\
1973 & National Park and Wildlife Conservation Act \\
1978 & Panchayat Forest Regulation \\
1981 & Forestry Sector Policy \\
1982 & Decentralization Act \\
1984 & Decentralization Regulation \\
1988 & Master Plan for the Forestry Sector \\
1993 & Forest Act \\
1995 & Forest Regulation \\
1998 & Local Self Governance Act
\end{tabular}

Source: Joshi (1997)

The Tenth Five Year plan (2002-2007) and the Poverty Reduction Strategy Paper (PRS-2002) of Nepal have envisioned good governance as one of the strategic pillars of development. Devolving and sharing of power with forest-dependantcommunities as forest good governance was started from enactment of Master Plan for the Forestry Sector (MPFS, 1989) and Forest Act 1993 (Table $1 \& 2)$. As the need of forest governance is to turn into more inclusive and pro poor in order to ensure well being of poor people (Arnold, 2001), NRM governance in Dolpa is in line with maintaining good governance fundamentals and well being of people and nature.

\section{Institution building}

Altogether, 193 community based organizations as NRM groups have been formed in Shey-Phoksundo National Park and buffer zone areas (Table 3). The community forest users groups, buffer zone user groups/committees, eco-clubs, snow leopard conservation committees, medicinal plant management committees, traditional health care centers/Myongkhang management committees (THCCs), rangeland management committees, and 
Table 2: Forest resource management policies and their strategies

\begin{tabular}{lllll}
\hline \multicolumn{1}{c}{ Type } & \multicolumn{1}{c}{ 1978 Regulation } & 1979 Amendment & 1987 Amendment & 1995 Regulation \\
\hline $\begin{array}{l}\text { \% of benefit to the } \\
\text { communities }\end{array}$ & 40 & 75 & 100 & 100 \\
$\begin{array}{l}\text { Use of community } \\
\text { fund }\end{array}$ & $50 \%$ for forestry & $50 \%$ for forestry & $100 \%$ for forestry & $\begin{array}{l}\text { Surplus amount for } \\
\text { forestry }\end{array}$ \\
$\begin{array}{l}\text { Plan preparation } \\
\begin{array}{l}\text { Management } \\
\text { responsibility }\end{array}\end{array}$ & DFO & GFO & Community & Community \\
\hline $\begin{array}{l}\text { Source: Joshi (1997) } \\
\text { Government of Nepal }\end{array}$ & Government of Nepal & User committees & User groups \\
\hline
\end{tabular}

Source: Joshi (1997)

different siter groups were developed and strengthened. Unlike other areas, users and managers of natural resources of Dolpa district are greatly varied. Because of heterogeneous civil societies adopting varied resources and geographical complexities, governance interventions on resource management were less identical. Traditional health care centres/Myongkhang management committees with Amchis and local people were found to be effective to sustainably manage the medicinal plant resources (Lama et al. 2001) whereas community forest user groups and eco-clubs were efficient in managing the forests and creating greater awareness level in lower Dolpa.

Sister groups were mean to empower the women and disadvantaged/marginalized groups while THCCs were meant to provide basic health care service in Upper Dolpa through sustainable management of medicinal and aromatic plants (MAPs). The snowleopard conservation committees were efficient in raising awareness and mobilizing the local communities towards wildlife (snow-leopard) conservation. Eco-clubs were sensitive to create awareness/education among the local communities about environment management while the forest user groups were responsive to sustainably manage the resources (Kunwar 2006). However, the buffer zone user committees were found to be less experienced and passively working.

Table 3: Community based organizations for natural resource management of SPNP and buffer zone area

\begin{tabular}{clc}
\hline S No. & \multicolumn{1}{c}{ Name of community-based organizations } & Total number \\
\hline 1 & Buffer zone user committees & 17 \\
2 & Buffer zone user council & 1 \\
3 & Community forest user groups & 21 \\
4 & Eco-clubs at community level & 19 \\
5 & Eco-clubs at school level & 28 \\
6 & Medicinal plant management committees & 3 \\
7 & Myongkhang management committees (THCC) & 2 \\
8 & Rangeland management committees & 41 \\
9 & Sister groups & 52 \\
10 & Snow-leopard conservation committees & 9 \\
\hline & Total & 193
\end{tabular}

\section{Capacity building}

The basic knowledge of NRM was endowed with several environmental education and awareness raising programs. Trainings/workshops/cross visits related to good governance, right based approach (RBA) and advocacy were important for building awareness on policies and regulations and advocating for policy dialogue at all levels. Public hearing together with public auditing and financial management interventions were instrumental in maintaining transparency within organizations. Furthermore, interventions helped participants to develop facilitation skills in delivery of rights and advocacy.

The interventions related to medicinal plants, their processing and marketing are crucial for livelihood of the local people particularly of the upper Dolpa. Nursery, cultivation and plantation related trainings led the communities to initiate to domesticate or cultivate useful and medicinal plants in their own private lands, which was imperative in Dolpa district (Kunwar, 2002). Some community led medicinal farms of selected species: Delphinium bimalayai (Atis), Valeriana jatamansii (Sugandhwal) etc. have been initiated in Raha VDC as inference of trainings. Traditional health care centers (THCCs) were effective in raising awareness and monitoring sustainable harvesting and conservation of medicinal plants in Phoksundo, Tinje, Vijer, Dho and Saldang villages. Free grazing was found to be controlled in 
the areas where medicinal plants were abundant. Plants like Dactylorbiza hatagirea (Hathajadi, Panchaunle), Neopicrorbiza scrophulariflora (Katuko), Atis, Sugandhwal, and Nardostachys grandiflora (Vulte, Jatamansi), and animals such as snow leopard, musk deer, etc are priority species of THCCs for conservation.

Apart from capacity building programs, other successful implementations were silvicultural operations; record keeping, minuting, auditing, monitoring, participatory decision making and benefit sharing, resource management and community development as per the operational plans, adequate representation of women and disadvantaged groups (DAGs) in the forest user group and key positions. The active involvement of the local institutions motivated the local people to participate in management activities and spell out without hesitation. The voice of primary users and local populace reflect the needy interventions to be accomplished.

The increment of women and disadvantaged beneficiaries in capacity building programs was found to be the most (Table 4). Beneficiaries of the women and disadvantaged community members increased from $21 \%$ in $2002 / 03$ to $31 \%$ in $2004 / 05$ and $12 \%$ in $2003 / 04$ to $23 \%$ in $2004 / 05$ to $22 \%$ respectively. Annual review, reporting as well as public hearing and public auditing were initiatives from the communities as indicating positive impact of capacity building programs upon the individuals and community groups. Public hearing and auditing were carried out in more than $10 \mathrm{CBOs}$ (CFUGs, BZUCs, and sister groups). The replication of public hearing and auditing and other financial management and administrative activities in other organizations was substantial because there were new $10 \mathrm{CBOs}$ who were preceded to have auditing. Similar trend of practice and replication of good governance fundamentals was observed in Banke district by Bhatta and Gentle (2004) and Thapa (2005). Decision making process in Dolpa was usually on consensus basis. Local level conflicts were resolved and small scale planning, monitoring and implementation of knowledge in the field were observed in the participatory manner.

Human capital has significantly been increased by investment in education and capacity building programs. Although the communities participated well in capacity enhancement activities and appreciated good governance, transparency and right based approach, they were more ease to have infrastructure development activities (construction and maintenance of bridges, roads, trails, water supply, mills, electricity etc.).

There was regular system of record keeping, minuting and monthly meeting. However the participation of women and disadvantaged groups was not satisfactory $(13.33 \%$ and $8.66 \%$ respectively as compared to $86.66 \%$ by men) in monthly meetings (Paudel 2004). 54\% users were found to be the regular attendant in the partidipatory meetings. There was punishment/rewarding system to motivate and encourage users to adopt in conservation and discourage to avoid rules and act illegal activities. Punishment and rewarding system was effectively carried out in CFUGs and BZUCs. The committee charges NRs 500 for criminals for the first time and up to NRs 5000 next time who performs illegal activities e.g. cut immature and pole-size trees. Special provisions and subsidy (1-2\%) to disadvantaged groups to promote/encourage them to participate actively in NRM were scheduled by CFUGs and BZUCs.

\section{Participation}

Because of the knowledge and idea of good governance, self-confidence and empowerment, community forest users have greatly promoted and ultimately accounted to have greater participation. Participation was found to be the most in capacity building and NRM programs. Involvement of women and DAGs in working groups was noticeable. There were respectively of $37.04 \%$ and $34.22 \%$ women and $8.77 \%$ and $7.44 \%$ disadvantaged group's

Table 4: Number of Beneficiaries of the capacity building programs

\begin{tabular}{clccc}
\hline \multicolumn{1}{c}{ Beneficiaries } & \multicolumn{1}{c}{ Sub-groups } & $\mathbf{2 0 0 2 / 0 3}$ & $\mathbf{2 0 0 3 / 0 4}$ & $\mathbf{2 0 0 4 / 0 5}$ \\
\hline Community member & Men & $148(79.14 \%)$ & $679(59.77 \%)$ & $312(68.57 \%)$ \\
& Women & $39(20.85 \%)$ & $457(40.19 \%)$ & $143(31.42 \%)$ \\
\multirow{5}{*}{ Project staff } & DAG & $(\mathrm{NA})$ & $138(11.83 \%)$ & $104(22.85 \%)$ \\
& Men & $111(82.83 \%)$ & $309(93.92 \%)$ & $269(81.02 \%)$ \\
& Women & $23(17.16 \%)$ & $20(6.07 \%)$ & $63(18.97 \%)$ \\
& DAG & $(\mathrm{NA})$ & $2(0.60 \%)$ & $14(4.21 \%)$ \\
\hline
\end{tabular}


representation in executive committees and key positions (President, Vice president, General secretary, Treasurer and Secretary) (Table 5).

Prioritization and inclusion of disadvantaged groups, ethnic groups and women in newly formed and renewed operational plans were most. Gender, equity and good governance issues have been addressed in the newly formed and renewed operational plans. Particularly, the increment of women and disadvantaged groups in renewed operational plans was important (Table 6). Similar observations were also noted by Pokharel and Nurse (2004), Maharjan et al (2004), Bhatta and Gentle (2004), Chowdhary (2004) and Dhital et al. (2004) from different areas of Nepal. Such adequate and increasing trend of representation of women and disadvantaged groups in committees and key positions were noticeable. The increment due to good governance system was more remarkable in other areas than Dolpa district (Table 7) owing to awareness level of users and complex physiography.

\section{Equity}

Of the total 1863 households of CFUGs in Dolpa district, 33.76\% households including 3.97\% households of disadvantaged groups are found to be benefited from the equitable distribution of the resources. They have been benefited and received subsidy to install the eco-friendly devices. Moreover, more than 20\% disadvantaged groups and 30\% women users of the total beneficiaries have been benefited from the capacity building programs (Table 4). Most of the participants of the capacity building programs were used to share knowledge within participants and family members. As a result, awareness and capacity on NRM (especially species and forest conservation) was greatly generated. To maintain equity on resource access, some criteria have been adopted by sister groups to select the users/ participants such as one representative from key positions, one representative from committee members and others from users; rotational basis; importance given to interested, subject matter related and disadvantaged groups and women and priority to the location/local situation. Though there was progressive trend of participation and access to the resources/opportunities of disadvantaged and women groups, their role in decision making to benefit sharing and equity was inadequate. Empowerment as well as more exposures and scopes are requisite for women and disadvantaged groups for their confidence, and active participation in decision making.

\section{Fund mobilization}

Mobilization of group fund in CFUGs was important. Groups were found to be mobilized their group fund to the various community development and forest management activities as major headings (Figure 1). The highest percentage of investment was found in community development and empowerment to women and disadvantaged groups. Community

Table 5: Representation of men, women and disadvantaged groups in management committee and key position

\begin{tabular}{lcccccc}
\hline \multirow{2}{*}{ User group } & \multicolumn{2}{c}{ Executive committee member (\%) } & \multicolumn{3}{c}{ Key position (\%) } \\
\cline { 2 - 7 } & Men & Women & DAG & Men & Women & DAG \\
\hline CFUGs (21) & 72.80 & 27.10 & 11.40 & 88.88 & 11.11 & 6.17 \\
BZUCs (17) & 85.00 & 15.00 & 9.10 & 96.70 & 3.12 & 6.45 \\
All CBOs (193) & 62.95 & 37.04 & 8.77 & 65.77 & 34.22 & 7.44 \\
\hline
\end{tabular}

Table 6: Number of users and committee members in renewed operational plans

\begin{tabular}{|c|c|c|c|c|c|c|c|c|c|}
\hline \multirow[b]{3}{*}{ ECM } & \multicolumn{3}{|c|}{ Before renewal } & \multicolumn{3}{|c|}{ After renewal } & \multicolumn{3}{|c|}{$\%$ of increase } \\
\hline & Men & Women & DAG & Men & Women & DAG & Men & Women & DAG \\
\hline & $27(87 \%)$ & $4(13 \%)$ & $1(3.2 \%)$ & $30(77 \%)$ & $9(23 \%)$ & $3(7.6 \%)$ & $11.11 \%$ & $125 \%$ & $200 \%$ \\
\hline User & \multicolumn{2}{|c|}{292} & 26 & \multicolumn{2}{|c|}{319} & 35 & \multicolumn{2}{|c|}{$9.42 \%$} & $34.61 \%$ \\
\hline
\end{tabular}

$\mathrm{ECM}=$ Executive committee member, $\mathrm{DAG}=$ Disadvantaged group

Table 7: Number of executive committee member

\begin{tabular}{lcccc}
\hline \multirow{2}{*}{ User type } & \multicolumn{2}{c}{ SAGUN Nepal program } & \multicolumn{2}{c}{ NMCP/SAGUN Dolpa program } \\
\cline { 2 - 4 } & $\mathbf{2 0 0 2 / 0 3}$ & $\mathbf{2 0 0 3 / 0 4}$ & $\mathbf{2 0 0 4}$ & $\mathbf{2 0 0 5}$ \\
\hline Women & $38 \%$ & $42 \%(4 \% \uparrow)$ & $27.10 \%$ & $27.18 \%(0.08 \% \uparrow)$ \\
DAG & $8 \%$ & $13 \%(5 \% \uparrow)$ & $10.80 \%$ & $12.13 \%(1.33 \% \uparrow)$ \\
Poor & - & - & $68.50 \%$ & $54.36 \%(14.14 \% \downarrow)$ \\
\hline
\end{tabular}


development and the NRM activities were comprehended with the way of transparent and accountable use of the resources and group fund. Particularly, the community development and NRM and environmental education and awareness programs were run by the sister groups and forest and buffer zone user committees and by the ecoclubs and snow leopard conservation committees respectively. Species conservation, habitat management and medicinal plant management were effective in upper Dolpa.

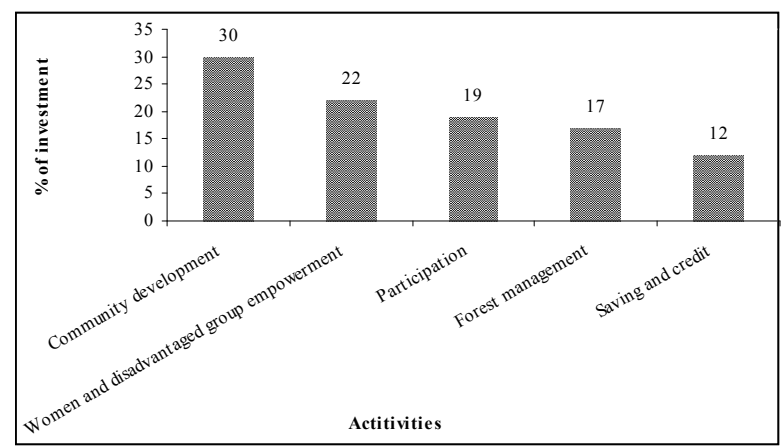

Figure 1: Mobilization of resources/fund

Maintenance and construction of school, road, trail, bridge, drinking water, mill, etc. were major community development activities. Many community development works such as awareness and education, plantation and care, support to maintain community hygiene, prohibit/control the use of polythene bags and pollution, and activities regarding cultural development, participation in fair/special day, antipoaching and hunting programs were carried out by sister groups and CFUGs with the help of ecoclubs.

Nursery development, plantation, seedling production, collection and harvesting, etc. were major activities of CFUGs. Grants and loan for users for income generation activities, support school programs, employment to the users and disadvantaged groups, etc. were also observed. The increasing trend of stall feeding and participatory protection in the district have led to sustainable forest resource management. But, as in community forestry in the other areas of Nepal, strong conservation approach in community forests of buffer zone areas of Dolpa district has posed some difficulties in sustainable uses of natural resources (Singh and Bajracharya, 2002).

Limited forest resources of Dolpa district have been exacerbated due to increasing human pressures namely forest fire, grazing, irrational collections, etc
(Kunwar and Adhikari, 2005). Alternative energy devices (solar, improved cooking stoves) that reduce the drudgery of the rural population by cutting down the time required to collect and use traditional forms of energy such as fuelwood, animal wastes etc. and harmonize people and nature, have been gaining momentum in Dolpa district. However, there was lack of technical manpower for proper handling and maintenance of the devices. The contribution from solar sets was important to reduce health and socioeconomic impacts (Khatri, 2005) and there was $22 \%$ reduction in fuelwood consumption after using the improved cooking stoves (Dhital, 2005).

\section{Forest/species conservation}

Participatory forest inventory and monitoring were effective in Dolpa district. In order to encourage local communities for forest/species conservation and to increase production of fodder, fuelwood and timber, some forest nurseries have been established at local level. Sallo, Loti (Olea sp.), Apple (Malus sp.), Juglans regia (Okhar), Bains (Salix) spp., etc. were produced and grown in nurseries. Active involvement of sister groups, eco-clubs, buffer zone user committees and community forest user groups was noticed in nursery management, and seedling/sapling transplantation. The involvement was of $60 \%$ of poorer communities and $10 \%$ of disadvantaged groups. Of the total plantations, $72 \%$ were found to be successful (SPNP/ NMCP, 2005). Besides plantations, forests were sustainably conserved with the active participation of user groups. Forest area under active management was found to have increased significantly from very beginning. The area under active management was 54 ha in 2002/03, 211 ha in 2003/04 and 236 ha in 2004/05 (SPNP/NMCP, 2005). However, weak technical and managerial capacities in community forest user groups (Sharma and Acharya, 2004) have weakened the good governance efficacy.

There were community based MAPs nurseries in Tripurakot and Pahada VDCs to propagate and multiplicate the MAPs cultivation at community level. The seedlings of Panchaunle, Jatamansi, Sugandhwal, Atis and Okhar species have been produced and transplanted. Medicinal plant management committees (MPMC) were established to overall manage the medicinal plant conservation. Significant number $(20.5 \%)$ of disadvantaged users from community forest user groups have been involved in cultivation and sustainable harvesting of NTFPs. 


\section{Constraints and recommendations}

There were very limited field movements that impeded program implementation, follow up and monitoring. Because of the limited movements, there was lesser involvement of local community in various activities. The lesser involvement was also due to the lack of awareness in the local communities. Conflict mediation sometimes became complex because of the lack of knowledge and understanding the relevant policies, regulations and guidelines and stakeholders' roles, rights and responsibilities. Capacity building campaigns and implementation procedures (as suggested by Pokharel and Niraula, 2004) for local community would be instrumental for sustainable management.

More emphasis/initiatives to encourage/empower disadvantaged groups to participate in various activities and join in user groups are imperative. To assist the user groups to gain confidence, the partner organizations need to provide adequate post formation supports. The delivery of knowledge/skills on sustainable and optimum use of resource and effective utilization of community fund should be through community based approaches and collaborative initiatives. Communication, coordination and network of users to make their voice heard in policy considerations should be strengthened.

Despite the plantation was common to all user groups, very few plantations succeeded due to lack of post management supports. Particularly, the least survival rate of transplanted seedlings and saplings was due to inadequate fencing, irrigation and post plantation management regimes. Fencing and irrigation facility should equally be given priority in plantation areas as post management support. Community based organizations have been formed but there was no platform or support or environment to internalize the acquired knowledge. Because of inadequate support and follow up actions, the efficacy of users and $\mathrm{CBOs}$ has come down leading to deterioraties of infrastructures. The severely affected infrastructures were water mills of Phoksundo, plantations in Rumo, Maddu and Raha, and vegetable farming in Raha and Maddu, etc.).

Participatory monitoring practice should be well encouraged for maintaining and developing the plantation areas. Conservation/plantation of transitional lands (lands between agricultural land and forest) would be better than carrying out plantation in bare and open areas. Livelihood of the people will be improved by providing adequate interventions in income generating activities and entrepreneurship. Particularly, carpet weaving, sheep/goat farming, livestock rearing and cheese production, medicinal plant cultivation and enterprise development/ entrepreneurship are potential income generating activities. Following operational strategies are required to make a shift to achieve the sustainable good governance practice.

\section{Conclusion}

In conclusion, NRM in Dolpa is in line with maintaining good governance fundamentals and well being of people and nature. However, participatory monitoring, post formation support and additional incentives for income generating activities are imperative.

\section{Acknowledgement}

WWF Nepal SAGUN Program is gratefully acknowledged for providing financial support to carry out the study.

\section{References}

Arnold, J. E. M. 2001. Forests and people: 25 years of community forestry. FAO Rome.

Bhatta, B. and Gentle, P. 2004. Strengthening the internal governance of CFUGs: experience from SAMARPAN project. In Twenty five years of community forestry (eds) Kanel, K. R., Mathema, P., Kandel, B. R., Niraula, D. R., Sharma, A. R. and Gautam, M. Proceedings of the fourth national workshop on community forestry, 4-6 August, 2004, Kathmandu, 508-514.

Chowdhary, C. L. 2004. Governance in community forest user groups in the perspective of post formation support. In Twenty five years of community forestry (eds) Kanel, K. R., Mathema, P., Kandel, B. R., Niraula, D. R., Sharma, A. R. and Gautam, M. Proceedings of the fourth national workshop on community forestry, 4-6 August, 2004, Kathmandu, 515-520.

Dhital, B. 2005. Ecological and socioeconomic impacts of adopting alternative energy Improved cooking stoves in Shey-Phoksundo National Park and its buffer zone area, Nepal (Thesis, CIS). Purbanchal University, Kathmandu, 22p.

Dhital, R. M., Rai, C. B. and Regmi, N. P. 2004. Governance in community forestry: field experiences from Churia forest development project. In Twenty 
five years of community forestry (eds) Kanel, K. R., Mathema, P., Kandel, B. R., Niraula, D. R., Sharma, A. R. and Gautam, M. Proceedings of the fourth national workshop on community forestry, 4-6 August, 2004, Kathmandu, 521-530.

Fowler, A. 1998. Striking a balance: a guide to enhancing the effectiveness of NGOs in international development. Earthscan publications, London, UK.

Ives, J. D. 2006. Himalayan perceptions: environmental change and the well being of mountain peoples. Himalayan Association for the Advancement of Science (HimAAS), Lalitpur, Nepal.

Joshi, A. L. 1997. Empowering local users in the forest management of Nepal. A paper presented at the workshop on economic globalization and environment sustainability in South Asia. 2-6 June, 1997, India.

Kafle, S. 2060. Nepalma Sthaniya Shusan Ra Garibi Niwaran. Kathmandu, Nepal.

Khatri, N. B. 2005. Ecological and socioeconomic impacts of adopting alternative energy Solar plant in Shey-Phoksundo National Park and buffer zone area, Nepal (Thesis). Trichandra Campus, Tribhuvan University, Nepal, 45p.

Kunwar, R. M. 2002. Some threatened medicinal and aromatic plants: Status, trade and management practice in Dolpa district, mid-west, Nepal. Journal of Natural History Museum 21:173-186.

Kunwar, R. M. and Duwadee, N. P. S. 2003. Ecology and economy of NTFPs in Nepal: a case study from Dolpa and Jumla district, Nepal. Botanica Orientalis, 3: 89-97.

Kunwar, R. M. and Adhikari N. 2005. Ethnomedicine of Dolpa district, Nepal: the plants, their vernacular names and uses. Lyonia 8(1): 43-49 www.lyonia.org.

Kunwar, R. M. 2006. Case studies of impacts of strengthened actions for governance in utilization of natural resources (SAGUN) program implementation in Shey-Phoksundo National Park and buffer zone area, Nepal. [Report], WWF Nepal Programme, Kathmandu, Nepal.

Lama, Y. C., Ghimire, S. K. and Thomas, Y. A. 2001. Medicinal plants of Dolpo: Amchi's knowledge and conservation. People and Plants and WWF Nepal, Kathmandu, Nepal.

Maharjan, M. R., Acharya, B., Lamichhane, R. P., Sharma, N. N., Pradhan, B. R. and Paudel, T. P. 2004. Operationalisation of good governance in community forestry: an experience from SAGUN programme. In Twenty five years of community forestry (eds) Kanel, K. R., Mathema, P., Kandel B. R., Niraula D. R., Sharma A. R. and Gautam M. Proceedings of the fourth national workshop on community forestry, 4-6 August, 2004, Kathmandu, 531-537.
Mc Dougall, Paudel, K. P. and Pandit, B. H. 2004. Effective adaptive capacity: a missing link in good governance in community forest user groups? In Twenty five years of community forestry (eds) Kanel, K. R., Mathema, P., Kandel B. R., Niraula D. R., Sharma A. R. and Gautam M. Proceedings of the fourth national workshop on community forestry, 4-6 August, 2004, Kathmandu, 358-370.

MFSC. 1989. Master Plan for Forestry Sector. Ministry of Forests and Soil Conservation, Kathmandu, Nepal.

Paudel, B. C. 2004. Community forests and sustainable resource utilization: a study of CFUGs in SheyPhoksundo National Park, Dolpa, Nepal. Trichandra Campus, Tribhuvan University (Thesis). Kathmandu, Nepal.

Pokharel, B. K. and Niraula, D. R. 2004. Community forestry in Nepal: achievements, challenges and options for future. In Twenty five years of community forestry (eds) Kanel, K. R., Mathema, P., Kandel B. R., Niraula D. R., Sharma A. R. and Gautam M. Proceedings of the fourth national workshop on community forestry, 4-6 August, 2004, Kathmandu, 298-316.

Pokharel, B. K. and Nurse, M. 2004. Forests and people's livelihood: benefiting the poor from community forestry. Journal of Forest and Livelibood 4(1):19-29.

Sharma, N. N. and Acharya B. 2004. Good governance in Nepal's community forestry: translating concepts into actions. In Twenty five years of community forestry (eds) Kanel, K. R., Mathema, P., Kandel B. R., Niraula D. R., Sharma A. R. and Gautam M. Proceedings of the fourth national workshop on community forestry, 4-6 August, 2004, Kathmandu, 422-432.

SPNP/NMCP. 2003. Annual Technical Progress Report (2002-2003). Department of National Park and Wildlife Conservation, WWF Nepal Program, Kathmandu, Nepal.

SPNP/NMCP. 2004. Annual Technical Progress Report (2003-2004). Department of National Park and Wildlife Conservation, WWF Nepal Program, Kathmandu, Nepal, 81 p.

SPNP/NMCP. 2005. Annual Technical Progress Report (2004-2005). Department of National Park and Wildlife Conservation, WWF Nepal Program, Kathmandu, Nepal.

Thapa, K. B. 2005. An assessment of governance status of CFUGs in Banke district, Nepal. (Thesis). Institute of Forestry, Tribhuvan University, 58p.

UNDP. 1997. Nepal human development index report. UNDP, Kathmandu, Nepal .

UNDP. 1999. Report on governance of third world. UNDP, Kathmandu, Nepal. 